\title{
Default of Banking Credit Agreements in the Time of Covid 19
}

\author{
Sri Dewi ${ }^{1}$, Sriono $^{2}$, Elviana Sagala $^{3}$ \\ ${ }^{1,2,3}$ Law Study Program, Faculty of Law, Labuhanbatu University, Indonesia \\ Sriono.mkn@gmail.com
}

\begin{abstract}
The covid 19 pandemic resulted in a very significant economic impact, and resulted in many defaults on bank credit agreements which underwent payment restructuring based on the covid 19 virus. Financial Services Authority (OJK) Regulation No. 11/POJK.03/2020 concerning the national economic stimulus as a countercyclical policy for the impact of the spread of covid 19 gives authority to banks to establish policies that support economic growth stimulus for debtors affected by the spread of covid 19, one of which is credit or financing restructuring policies. The occurrence of a national disaster caused by the Covid 19 virus had an impact on the force majeure situation. That defaults due to the spread of the covid-19 virus have resulted in debtors being negligent in carrying out their obligations, this method uses the normative juridical method, which refers to the provisions of positive laws and regulations in Indonesia. The results of the research show that defaults in the credit agreement cannot be used as an excuse for not fulfilling their obligations. The spread of covid-19 cannot be used as an excuse that causes a compelling situation that requires the debtor to commit an act of default. In the concept of a rule of law, judicial power is independent in carrying out its judicial function, thus enabling the exercise of judicial power to be fair in examining, adjudicating and deciding cases based on law and justice. Then the policy of the regulations issued by the government against the spread of the covid-19 virus is very important for the community regarding the problem of the spread of the covid-19 virus.
\end{abstract}

Keywords

default; agreement; credit; covid-19

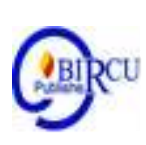

\section{Introduction}

One of the impacts of the spread of the covid-19 virus is the decline in the economy which results in default problems with credit agreements. Both in credit agreements (multi) leassing, bank credit agreements, and other credit agreements. As is well known, banking has a great influence in driving the country's economy. Because the main objective of a bank is to support the implementation of national development in order to increase equity, economic growth and national stability aimed at improving people's welfare. Thus, the bank as a financial institution has a very influential factor in moving the wheels of the economy (Sriwati, 2021). Default is the implementation of an unfulfilled obligation or a condition of broken promise or negligence committed by the debtor. Default is regulated in Article 1243 of the Civil Code (KUHPer), which reads: "Reimbursement of costs, losses and interest due to non-fulfillment of an engagement is obliged, if the debtor, has been declared negligent, remains negligent to fulfill the agreement, or if something must be given or done only within the time that has exceeded the stipulated time". 
The Covid-19 pandemic has affected the banking sector, such as a decline in financing, this decline was due to a decrease in the ability of customers to make payments (Ichsan et al., 2021). During the Covid-19 pandemic, cases of default on bank credit agreements were caused by a national disaster (force majeure). The occurrence of this pandemic also cannot be denied that it has caused many companies to experience losses, which has resulted in obstruction of achievement of other parties, thus causing default. The cause of the occurrence of default is the debtor does not do something or gives something that is not on time, and does something that is not right on the target agreed upon by both parties. A party can be declared in default based on article 1238 of the Civil Code. So that in order to sue a debtor who is in default (default) as implied in article 1243 of the Civil Code,(frans wempie supit pangemanan, 2019). If, according to the nature of the agreement, a period of time has passed, it means that the debtor has defaulted. Because the agreement is made based on a mutual agreement between the two creditors and debtors, based on the legal conditions an agreement is regulated according to article 1320 of the Civil Code.

The forms of default are (Mia Wijayanti Ekalandika, I Ketut Westra, 2013):

1. The debtor does not fulfill the achievement at all.

2. The debtor fulfills some of the achievements.

3. The debtor is late in making transactions.

4. The debtor was wrong in carrying out his performance.

5. The debtor does something that is prohibited in the contract.

The legal consequences for a debtor who has defaulted in an agreement are the following legal penalties or sanctions (Eka Nur Safitri, 2018):

1. The debtor is required to pay compensation that has been suffered by the creditor (article 1234 of the Civil Code).

2. If the engagement is reciprocal. Creditors can demand cancellation / cancellation of the engagement through a judge (article 1266 KUHPerdata).

3. In an agreement to give something, the risk is transferred to the debtor since default occurs (article 1237 paragraph 2 of the Civil Code).

4. The debtor is required to fulfill the agreement if it can still be done, or cancellation is accompanied by payment of compensation (article 1267 of the Civil Code).

5. The debtor is obliged to pay court fees if litigated before the District Court, and the debtor is found guilty.

The Banking Credit Agreement is expressly stated in the provisions of Article 1 number 11 of Law Number 7 of 1992 as amended by Act Number 10 of 1998 (hereinafter referred to as the Banking Law) In an agreement, the parties have their respective rights and obligations. The legal requirements for a Banking Credit Agreement based on Article 1338 of the Civil Code, it is stated that all agreements made legally are valid as law for those who make them. The agreements cannot be withdrawn other than the agreement between the parties, or for reasons which are stated by law to be sufficient for this. Article 1338 of the Civil Code provides an understanding that anyone who has entered into an agreement, then they will be bound to comply with everything that they have agreed upon, and this is the same as obeying a statutory provision. So, all agreements or the entire contents of the agreement must be obeyed by the parties as long as their making fulfills the legal requirements of an agreement, and as long as they are made the same as the laws and regulations.

The Banking Credit Agreement is the same in terms of validity as well as the validity of the agreement in general. Where there is an important legal principle related to the validity of the Agreement (contract) is the principle of freedom of contract (Servanda), meaning that the parties are free to determine and make any contract either those that 
already have arrangements or those that have not been regulated, either those that have been named or have not been named, and the parties are also free to determine the contents of the contract (Trisna, 2017). In practice, the current form and content of credit agreements differ from one bank to another.

However, the validity of a bank credit agreement making must be guided by the provisions contained in Article 1320 of the Civil Code which regulates the legal terms of an agreement, namely:

1. Agree those who bind themselves

2. The ability to make an engagement

3. A certain thing

4. A cause that is lawful

Bank credit agreements can be made with an authentic deed or with an underhand agreement. In the case of a bank credit agreement made under the hand, the notary's role is to legalize the underhand credit agreement. The authority of a Notary to legalize a deed or underhand agreement is regulated in Article 15 paragraph (2) of Law Number 2 of 2014 concerning Amendments to Law Number 30 of 2004 concerning Notary Position (hereinafter referred to as Law on Notary Position abbreviated as UUJN)(Ida Bagus Gde Gni Wastu, I Gusti Ngurah Wairocana, 2017). During the current pandemic, defaults on credit agreements often occur due to force majeure conditions.

In the law of agreement, in order to determine the condition of the debtor's default, a subpoena / warning letter / statement of negligence to the debtor is required. Somasi is a warning letter / notification from the creditor to the debtor that the debtor has neglected to carry out his obligations in accordance with what has been agreed in the agreement. With the provision of credit that will be carried out by creditors and collateral that will be fulfilled by the debtor, then objects are loaded with fiduciary guarantees (Sriono, 2019). The issue of executing fiduciary guarantees is very important for the bank, this is in accordance with the function of the guarantee right in the context of providing bank credit as a last resort so that the credit that has been channeled by the bank can be returned so that the bank does not suffer losses, the results of the execution / selling of the credit guarantee are intended for repayment debtor's debt, and if from the proceeds from the sale of the collateral object there is a remainder will be returned to the debtor, and vice versa if there is a deficiency, then the deficiency must be paid by the debtor using concurrent rights based on article 1131 of the Civil Code.

In the fiduciary guarantee agreement related to execution, it is stipulated in articles 29 to article 34 of Law Number 42 of 199 concerning Fiduciary Security. Furthermore, the execution of fiduciary security is an act of confiscation of objects used as collateral in the fiduciary guarantee agreement. The process of confiscation and sale of the object of this fiduciary guarantee occurs because the debtor has failed his / her promise / cannot carry out his performance in accordance with the agreement agreed upon, even though he has been given a summons by credit (Gentur cahyo setiono, herry sulistyo, 2021).

\section{Research Methods}

Legal research carried out due to the spread of the covid -19 virus caused the Indonesian state to experience a very significant economic decline, causing problems of default on bank credit agreements. The research method used in this study is to use the normative juridical method, which refers to the provisions of positive legislation in Indonesia. In this research, it refers to secondary data research. namely library research (library research), which is obtained through literature, by reviewing, analyzing, and 
managing the literature on legislation by means of researching through articles relating to the problems to be examined. The data obtained is then analyzed by observing the data obtained and then linking each data obtained with the provisions and legal principles related to the problems studied. The purpose of this research in default on the credit agreement is to provide an approach method with deductive thinking related to the way of thinking in drawing conclusions drawn from something that is general in nature which has been proven that he is correct and that conclusion is designated for something special through the role of the credit agreement, the role financial services authorities in the face of an economic downturn due to the impact of the spread of the covid-19 virus(Satradinata \& Muljono, 2020).

\section{Results and Discussion}

\subsection{The Role of the Financial Services Authority in Defaults on Bank Credit Agreements during the Covid-19 Period}

The role of the financial services authorities in dealing with non-preservation problems arising from the impact of the spread of the Covid-19 virus is by restructuring credit, by providing delays in credit payments for a period of 1 (one) year and reducing the interest set in POJK Number 11 / POJK.03 / 2020 concerning National Economic Stimulus as a Countercyclical Policy regulates that debtors who receive special treatment in this POJK are debtors (including MSME debtors) who have difficulty fulfilling obligations to the Bank because the debtor or debtor's business is directly affected by the spread of COVID-19 or indirectly in the economic sector, including tourism, transportation, hotels, trade, processing, agriculture and mining(Satradinata \& Muljono, 2020). The POJK clearly stipulates that in principle, banks can restructure all credit / financing to all debtors, including MSME debtors, as long as these debtors are identified as being affected by COVID-19. Giving special treatment regardless of credit / financing ceiling limits.

OJK Regulation No.11 / POJK.03 / 2020 concerning National Economic Stimulus as a Countercyclical Policy on the Impact of the Spread of Coronavirus Disease The stimulus policy consists of:

a. Assessment of the quality of credit / financing / other provision of funds is only based on the accuracy of principal and / or interest payments for loans up to IDR 10 billion.

b. Restructuring by increasing the quality of credit / financing to become smooth after restructuring. This restructuring provision can be applied by the Bank without a credit ceiling limit.

The quality of the restructured credit / financing can be determined to be smooth if it is given to debtors who are identified as being affected by the spread of Covid-19. Credit / financing restructuring is carried out in accordance with the POJK regarding asset quality assessment, among others by:
a. interest rate cut
b. extension of the period
c. reduction of principal arrears
d. reduction in arrears of interest
e. additional credit / financing facilities
f. conversion of credit / financing into Temporary Equity Participation

Crisis conditions The Indonesian economy is currently worsening due to the Covid19 pandemic which has disrupted the economy. re-registering negative growth, Indonesia is categorized as entering into a recession or economic decline. Some of the effects are increasing unemployment and poverty. The government must continue to maintain the 
independence of Bank Indonesia in handling the country's economic crisis. On the other hand, the government must also ensure that Bank Indonesia is alert to assist in handling the crisis. Therefore, the formulation of the Bank Indonesia Law must consider several things (Chandra, 2015):

a. Ensure that monetary decisions taken by Bank Indonesia must remain independent. This can be done by ensuring that the Monetary Board is controlled by the Governor of Bank Indonesia without interfering with the government.

b. The formulation of the Bank Indonesia Law needs to add an article regarding the coordination of the government and Bank Indonesia, especially in economic conditions that require sharing of burdens between the two.

However, in general, the regulatory and supervisory functions are not fully assigned to the Financial Services Authority, but the Financial Services Authority continues to collaborate with Bank Indonesia (BI), which has respective responsibilities and authorities that are mutually coordinating and integrated. The Financial Services Authority has a regulatory and supervisory function and authority in the microprudential scope, namely supervision that encourages individual financial institutions to remain healthy and able to maintain community interests, such as institutional regulation and supervision, health, prudential aspects, and auditors of financial institutions. Meanwhile, BI has the regulatory and supervisory function and authority in the microprudential scope,(Muhammad Fakhri Amir, 2020)Roles and Functions of the Financial Services Authority (OJK) in the Financial System Based on Law Number 21 of 2011 concerning the Financial Services Authority, it is stated that the Financial Services Authority is an integrated and independent institution that has functions, duties, and authorities in regulating the regulatory system to supervise the financial service activities. As well as the Financial Services Authority is an institution that is not part of the governmental power, and is carried out by applying the principles of good governance, which include accountability, transparency, independence, accountability and fairness.

The objectives of the establishment of the Financial Services Authority are to meet and protect the needs and interests of the community, create a stable and sustainable financial system, and maintain an orderly, fair, accountable and transparent financial system. Therefore, the Financial Services Authority has an important role in maintaining competitiveness and improving the economy in Indonesia. Decision of the Financial Services Authority on the banking stimulus policy:

1. Regulation of the Financial Services Authority of the Republic of Indonesia Number 11 / POJK.03 / 2020 concerning National Economic Stimulus as a Countercyclical Policy Impact of the Spread of Corona Virus Disease 2019 on March 16, 2020: This Financial Services Authority Regulation regulates relaxation of credit restructuring for debtors affected by the spread of Covid -19 both individuals, MSMEs, and corporations. The restructuring scheme is assigned to each bank according to the needs of the debtor and the capacity of the bank, while still observing the principle of prudence. Restructured loans are classified as current as of March 31, 2021.

2. Regulation of the Financial Services Authority of the Republic of Indonesia Number 18 / POJK.03 / 2020 concerning Written Orders for Handling Bank Problems on 21 April 2020: This Financial Services Authority Regulation regulates the authority of the Financial Services Authority to issue a written order to carry out a merger, consolidation, acquisition and / or integration (P3I) and receiving P3I, which aims to: a) Maintain financial system stability in the midst of the Corona Virus Disease 2019 (Covid-19) pandemic; b) Facing the threat of an economic crisis and / or financial system stability, 
3. Regulation of the Financial Services Authority of the Republic of Indonesia Number 34 / POJK.03 / 2020 concerning Policies for Rural Banks and Sharia Rural Banks as an Impact of the Spread of Coronavirus Disease 2019 on June 2, 2020: This provision provides relaxation for BPRs and BPRS during the Covid 19 period, among others, by reducing the calculation of Provision for Earning Asset Losses (PPAP), the value of Foreclosed Collateral (AYDA) as a deduction for core capital in the calculation of the Minimum Capital Requirement, and provision of funds in the form of placement of funds between banks in order to overcome BPR / BPRS liquidity problems. others, as well as a reduction in the percentage of funding for HR education and training.

After the issuance of the Financial Services Authority Regulation Number 11 / POJK.03 / 2020, it explains policies that support the stimulus of economic growth, but there are still problems of default on credit agreements due to the impact of Covid-19. Force majeure, namely in Article 1244 and Article 1245 of the Civil Code. As a reason to release the debtor's responsibility so that the force majeure is a reason to be exempted from the obligation to pay compensation. defense, the debtor tries to show that the failure of what was promised is due to things that are completely unexpected, and where it can do nothing about circumstances or events that arise outside of the expectations of the broad economy in Indonesia. In other words, the non-fulfillment of the agreement or the delay in carrying it out, was not due to his negligence. He cannot be said to be wrong or negligent, and a person who is not wrong should not be subject to the sanctions imposed for negligence. Such understanding is actually closely related to what is called good faith. Then what kind of regulatory policies can help in the problem of national disasters in Indonesia due to the impact of covid-19. the non-fulfillment of the agreement or the delay in carrying it out, is not the result of his negligence. He cannot be said to be wrong or negligent, and a person who is not wrong should not be subject to the sanctions imposed for negligence. Such understanding is actually closely related to what is called good faith. Then what kind of regulatory policies can help in the problem of national disasters in Indonesia due to the impact of covid-19. the non-fulfillment of the agreement or the delay in carrying it out, is not the result of his negligence. He cannot be said to be wrong or negligent, and a person who is not wrong should not be subject to the sanctions imposed for negligence. Such understanding is actually closely related to what is called good faith. Then what kind of regulatory policies can help in the problem of national disasters in Indonesia due to the impact of covid-19.

\subsection{Credit Agreement Default during the Covid-19 Period That Caused the District Court to Reject the Case}

The Indonesian government has designated Covid-19 as a type of disease that causes public health emergencies. Therefore, in order to inhibit the spread of Covid-19, the Government took steps to determine the Covid-19 pandemic as a national disaster and appealed to the public to take action.physical distancing and work / study from home. This government appeal was followed by the issuance of a number of legal umbrellas including Government Regulation Number 21 of 2020 concerning Large-Scale Social Restrictions in the Context of Accelerating Handling of Corona Virus Disease 2019 (Covid-19), Presidential Decree Number 11 of 2020 concerning Determination of Public Health Emergencies for Corona Virus Disease 2019 (Covid-19), Regulation of the Minister of Health of the Republic of Indonesia Number 9 of 2020 concerning Guidelines for LargeScale Social Restrictions in the Context of Accelerating the Handling of Corona Virus Disease 2019 (Covid-19), through Presidential Decree Number 12 of 2020 concerning Determination of Non-Natural Disasters for the Spread of Corona Virus Disease 2019 
(Covid-19) As a National Disaster(Rina Maulina, 2020).

According to the Regulation of the Financial Services Authority Number 11 of 2020, Banks can provide restructuring / credit relief / financing to debtors. The condition is that the debtor is affected by the spread of Corona Virus Disease 2019 (Covid-19), either directly or indirectly, which causes the debtor to experience difficulties in fulfilling obligations to the Bank (conventional commercial banks, including sharia business units, Islamic commercial banks, people's credit banks, Islamic people's finance bank). The types of debtor businesses that can be given a stimulus are those engaged in the economic sector, including tourism, transportation, hotels, trade, processing, agriculture and mining. However, it should be noted, the restructuring / credit relief policy / financing is left to the Bank.

In this case, the Bank will conduct a self-assessment with guidelines that at least contain the criteria for debtors and sectors affected by Covid-19. Then, what if the debtor does not meet the criteria set by the Bank, what about other business actors whose business activities are affected by Covid-19 but are not included in the criteria referred to in Financial Services Authority Regulation Number 11 of 2020 Can business actors apply for restructuring on the grounds of force majeure. Like the case that occurred in the Surabaya District Court which stated that the judge rejected the couple's bad credit lawsuit due to Covid-19(PT JAWA POS, nd). The panel of judges considered that the two plaintiffs had defaulted or broken their promises because they did not pay off their debts as agreed in the credit agreement. Before auctioning off the pledged assets, the bank sent a warning letter to the plaintiff (subpoena), but was not responded to. However, the defendant stated that he was in default due to a national disaster or force majeure.

When the judge rejects the lawsuit against the couple, whether the judge has carried out his duties properly, according to the judiciary, in the context of the Indonesian state, it is the power of an independent state to administer the judiciary in order to uphold law and justice based on Pancasila, for the sake of implementing the State of Law of the Republic of Indonesia. Number 4 of 2004 concerning Judicial Power regulates judicial bodies administering judicial power, the principles of administering judicial power, guaranteeing the same position and treatment for everyone in law and in seeking justice. Law Number 4 of 2004 has been amended into law Law No.48 of 2009 concerning Judicial powers.

The role of the judicial power plays an important role in considering or deciding a case in court. If in resolving disputes and deciding cases judges ignore morals, it will certainly result in a fair but false decision or result in a false justice. Moral norms for judges in carrying out their duties are regulated in the Joint Decree of the Supreme Court of the Republic of Indonesia and the Chairman of the Judicial Commission of the Republic of Indonesia Number 047 / KMA / SKB / IV / 2009 and Number 02 / SKB / P-KY / IV / 2009 concerning Code of Ethics and Guidelines Judges' behavior, which regulates judge behavior as follows: behave fairly, behave honestly, behave wisely and wisely, be independent, have high integrity, be responsible, uphold self-respect, have high discipline, behave humbly, behave professionally.

The principle of freedom of judges in carrying out their duties as judges can be interpreted that judges in carrying out the duties of judicial power must not be bound by anything and / or pressured by anyone, but are free to do anything. Interpreting the meaning of such freedom is called individual freedom or essential freedom. Implementation of the principle of freedom of judges in deciding a case in which they are handled. Judges are free from interference by extra-judicial powers, both executive and legislative powers and other extra-judicial powers in society, such as the press. Judges in examining and judging are free to determine their own ways of examining and judging, 
freedom of judges means freedom in the context of freedom of the judiciary. The independence of the judicial power which is guaranteed by the basic laws of the country and the laws and regulations under it, is inherently carried out by Court judges from the judiciary in all areas of the judiciary in carrying out the functions of power in the judicial sector. The existence of judicial power shows that Indonesia is a state based on law. The demands of the judges are none other than the legal consequences and the professionalism of the judges in carrying out the function of the power of the judiciary to uphold law and justice through judicial bodies.(Sagala, 2017). The independence of judges in carrying out the functions of judicial power through state judicial bodies is intended so that judges can truly be independent, free and free from all interference that may affect their function in examining, judging and deciding a case before them.

\section{Conclusion}

The spread of the Covid-19 virus can cause a debtor to default. The role of the Financial Services Authority is very influential in the current economic crisis. after the issuance of the Financial Services Authority RegulationNo.11 / POJK.03 / 2020 concerning National Economic Stimulus as a Countercyclical Policy on the Impact of the Spread of Coronavirus Disease Stimulus policy, through credit restructuring for a period of 1 (one) year.The steps taken by banks in the policy of reducing funding due to Covid-19 refer to the Financial Services Authority Regulation No.11 / POJK.03 / 2020 concerning National Economic Stimulus as a Countercyclical Policy on the Impact of the Spread of Coronavirus Disease. In the Financial Services Authority Regulation, it states that banks can implement policies that can support economic growth for bank financing customers who are affected by the spread of Covid-19. Customers who get a restructuring relief policy are customers who have been directly or indirectly affected by Covid- 19 .

The bank's policy is to provide customers affected by the Covid-19 pandemic in the form of relaxation of financing facilities in the form of postponement of payments and provision of margin relief (profit sharing) whose timeframe and conditions are adjusted to the economic sector, criteria and conditions of customers by referring to the provisions of the Financial Services Authority. .In the agreement, there are parties who are obliged to carry out an achievement and parties who are entitled to an achievement. In fulfilling an achievement on an agreement that has been made by the parties, it is not uncommon for the debtor (customer) to neglect to carry out their obligations or not to carry out their obligations or not to carry out all their achievements, this is called default. legal consequences if the debtor defaults in the credit agreement, namely the debtor is required to pay compensation, the creditor can demand the cancellation of the agreement, the debtor is required to fulfill the agreement if it can still be done, the debtor is required to pay court fees if litigated before the District Court,

The Covid-19 that occurred did not affect the problem of bad credit or default. Several cases of bad credit or default that have been submitted to the Court are totally rejected by the Judge. Judges' considerations in rejecting decisions based on regulations on judicial freedom. Several policies related to Covid-19 cannot be taken into consideration by judges in deciding cases of bad credit or default between debtors and creditors (banks). 


\section{References}

Chandra, M. J. A. (2015). Kewenangan Bank Indonesia Dalam Pengaturan Dan Pengawasan Perbankan Setelah Terbitnya Undang-Undang No. 21 Tahun 2011 Tentang Otoritas Jasa Keuangan. Jurnal Hukum Sehasen, 1(1), 24-45.

Eka Nur Safitri. (2018). Analisis Faktor - Faktor Penyebab Terjadinya Wanprestasi Dan Penyelesaiannya Pada Produk Murabah. In Journal of Chemical Information and Modeling (Vol. 53, Issue 9).

frans wempie supit pangemanan. (2019). Implementasi Pasal 1238 Kuh Perdata Terhadap Penentuan Debitor Yang Cidera Janji Dalam Perjanjian Kredit. Lex Et Societatis, 7(4), 119-126.

Gentur cahyo setiono, herry sulistyo, satriyani cahyo widayati. (2021). Cidera Janji Dalam Perjanjian Kredit Jaminan Fidusia. TRANSPARASI HUKUM, 04(01), 62-76.

Ichsan, R. N., Suparmin, S., Yusuf, M., Ismal, R., \& Sitompul, S. (2021). Determinant of Sharia Bank's Financial Performance during the Covid-19 Pandemic. Budapest International Research and Critics Institute (BIRCI-Journal): Humanities and Social Sciences, 4(1), 298-309. https://doi.org/10.33258/birci.v4i1.1594

Ida Bagus Gde Gni Wastu, I Gusti Ngurah Wairocana, D. P. D. K. (2017). Kekuatan Hukum Perjanjian Kredit Di Bawah Tangan Pada Bank Perkreditan Rakyat. Acta Comnitas, 2(1), 83-98. https://doi.org/10.24843/AC.2017.v02.i01.p08.

Mia Wijayanti Ekalandika, I Ketut Westra, D. G. R. (2013). wanprestasi dalam perjanjian kredit bank rakyat indonesia (PT PERSERO) Tbk Cabang Denpasar. Kertha Semaya : Journal Ilmu Hukum, 01(08), 1-6.

Muhammad Fakhri Amir. (2020). Peran Dan Fungsi Otoritas Jasa Keuangan (OJK) Dalam Sistem Keuangan Di Indonesia (Perspektif Hukum Islam). Al-Amwal, Journal of Islamic Economic Law, 5(1), 1-20. https://doi.org/10.24256/alw.v5i1.1577

PT JAWA POS. (n.d.). hakim menolak gugatan pasutri.

Rina Maulina, R. M. (2020). Retrukturisasi Kredit Dalam Pelaksanaan Kebijakan Countercyclical Dampak Penyebaran COVID-19 DI PT. BPRS Baiturrahman. AKBIS, Media Riset Dan Akuntansi, 4(1).

Sagala, B. B. (2017). Kekuasaan Kehakiman yang Merdeka. Jurnal Hukum \& Pembangunan, 16(2), 153. https://doi.org/10.21143/jhp.vol16.no2.1197

Satradinata, D. N., \& Muljono, B. E. (2020). Analisis Hukum Relaksasi Kreadit Saat Pandemi Corona Dengan Kelonggaran Kredit Berdasarkan Peraturan Otoritas Jasa Keuangan Nomor 11/POJK.03/2020. Jurnal Sains Sosio Humaniora, 4(2), 613-620. https://doi.org/10.22437/jssh.v4i2.11009

Sriono, S. (2019). Tanggung Jawab Pemberi Fidusia Terhadap Benda Jaminan Fidusia Dalam Perjanjian Kredit. Jurnal Ilmiah Advokasi, 07(02), 149-159.

Sriwati. (2021). Legal Protection for Creditor under Cross Default and Cross Collateral Clause in a Credit Agreement. Konfrontasi Journal: Culture, Economy and Social Changes, 8(1), 12-22. https://doi.org/10.33258/konfrontasi2.v8i1.137

Trisna, N. (2017). Aspek Hukum Pencantuman Klausula Eksonerasi Dalam Perjanjian Kredit Perbankan. Ius Civile, 1(1), 78-92. 